\title{
The Effect of Flipped Learning to Improve the Reading Comprehension of College Students of Elementary School Teacher Study Program on Pandemic Covid-19
}

\author{
Puji Hariati ${ }^{1, *}$ Nurul Husnah Harahap ${ }^{2}$ Mery Silalahi $^{3}$
}

\author{
${ }^{1}$ Akademi Informatika dan Komputer Medicom \\ 2 Akademi Informatika dan Komputer Medicom \\ ${ }^{3}$ Institut Agama Kristen Negeri Tarutung \\ *Corresponding author. Email: zeenasution@gmail.com
}

\begin{abstract}
Technology advances have brought significant changes in the teaching and learning practices of foreign languages in Indonesia, especially in learning English. Teaching or delivery of subject matter that should be done by lecturers in the classroom can now be done outside the classroom because of technology. Technology has become an important part of the teaching and learning process. The use of technology in teaching is considered effective in facilitating lecturers in delivering learning material and also making it easier for students to understand the material presented. More than that, technology is also able to create great opportunities for everyone to develop themselves through knowledge that can be accessed at any time, anytime and anywhere. This is the reason for educators to create technology-based learning models, especially during the Covid-19 pandemic. The use of appropriate technology in the learning process is considered to be able to improve the quality of the knowledge that students have for the better. Technology has changed the face of education, the proof is that currently teaching and learning activities are carried out online. Even so, students in the learning process still really need lecturers who teach directly in the classroom as providers of knowledge and motivation to achieve maximum learning outcomes. Realizing this fact, educators try to take advantage of technology in the learning process by maintaining face to face between lecturers and students in the implementation of teaching and learning activities in the classroom through the flipped learning model. Flipped learning is a learning system that utilizes technology in the form of video while maintaining face to face between lecturers and students in the class. Flipped learning is also known as reverse class because students are required to be more active in investigating at home the problems found in any subject matter that has been previously studied. Students are also allowed to record videos of lecturers delivering lesson material, and then the results of the video recordings will be watched at home to be observed and analyzed by themselves. With flipped learning, students are expected to receive more frequent exposure to English both orally and in writing. The spoken English exposure can be seen and heard repeatedly through the recorded video. The oral English exposure can then be rewritten into written text, so that indirectly the listening and writing competences of students become increasingly honed. All activities of watching and listening to videos as well as writing English subtitles were carried out at home. This can make students more free to experiment at home because they don't need to be embarrassed if they are wrong. As for the things that students will not understand from the video, they can then be conveyed to the lecturer during the learning process. Thus, flipped learning is believed to be a learning model that can improve students' reading comprehension of English texts.
\end{abstract}

Keywords: flipped learning, English, video.

\section{INTRODUCTION}

Technological advances have brought significant changes in the teaching and learning practices of foreign languages in Indonesia, especially in learning English. Teaching or delivery of subject matter that should be done by lecturers in the classroom can now be done outside the classroom because of technology. Before technological developments appeared as they are today, the teaching and learning process, which we know as conventional learning models, required face-to-face contact between lecturers and students in the classroom. 
In conventional learning, the entire process of teaching and learning activities is carried out in the classroom. Lecturers usually deliver subject matter with the lecture method, supported by learning media, which are usually prepared as a way to facilitate the delivery of material. In this learning model, students feel it is enough just by listening and paying attention to the material presented by the lecturer in front of the class. This makes students less active in responding to learning due to the one-way learning activities experienced by students, where students sit listening and take notes on the subject matter while the lecturer gives lectures conveying theories in front of the class. This is commonly happened for several meetings, which makes the learning process becoming monotonous.

This conventional learning model can no longer meet today's demands, especially during the Covid-19 pandemic. Currently all human activities are inseparable from technology, as well as in the world of education related to teaching and learning. Technology has become an important part of the process of teaching and learning activities. The use of technology in teaching is considered effective in facilitating lecturers in delivering learning material and also making it easier for students to understand the material presented. More than that, technology is also able to create great opportunities for everyone to develop themselves through knowledge that can be accessed at any time, anytime and anywhere. This is the reason for educators to create technology-based learning models. The use of appropriate technology in the learning process is considered to be able to improve the quality of the knowledge that students have for the better.

Technology has changed the face of education, the proof is that currently teaching and learning activities can be done online. Even so, students in the learning process still really need a lecturer who teaches directly in the classroom as a provider of knowledge and motivation to achieve maximum learning outcomes. Realizing this fact, educators try to take advantage of technology in the learning process by maintaining face to face between lecturers and students in the implementation of teaching and learning activities in the classroom through the flipped learning model. Flipped learning is a learning system that utilizes technology in the form of video while maintaining face to face between lecturers and students in the class. Flipped learning is also known as reverse class because students are required to be more active in conducting home investigations of the problems found in any subject matter that has been previously studied at school. Students are also allowed to record videos of lecturers delivering course material online, and then the results of the video recordings will be watched at home to be observed and analyzed by themselves. In flipped learning, $58 \%$ of the time spent studying at home is maximized by reading the subject matter and $21 \%$ of the time is spent watching videos of the teaching and learning process that is taking place. From the videos observed, students will see and judge for themselves the strengths and weaknesses obtained in the learning process. Here, students have indirectly evaluated the learning process itself. From the results of student observations of the video, as much as $6 \%$ of the time will be used by students to prepare questions which will then be discussed or discussed at the next meeting.

The use of study time will later be used as much as $13 \%$ to discuss questions that have been prepared at home related to subject matter that has been taught previously and $43 \%$ of the time online is done for problem solving of any existing questions regarding the subject matter. In this case, we can conclude that in the flipped learning model, students are required to be active learners. This can be seen from the time spent by students both at home and at school is to build knowledge based on experience obtained from problems found in each subject matter and how to solve it.

As stated by Bergmann, J., and Sams, A. (2012), flipped learning is not online learning or not about replacing lecturers with video but a learning model that spurs students to use their own knowledge to find existing problems and try to solve or looking for solutions to any existing problems by discussing with peers and lecturers, so that from the discussion students will learn a lot and get new knowledge. The role of lecturers in flipped learning is not merely a stage actor as seen in conventional learning models, but as a facilitator, namely guiding students to find their own knowledge by making them active learners.

This flipped learning model is believed to be appropriate for use in foreign language learning such as in English lessons. The difficulty that is often experienced by PGSD students in learning English is understanding the English text itself. This could be caused by a lack of English vocabulary (vocabulary) owned by students or it could also be caused by the lack of exposure to English received by students, both orally and in writing. In addition, the monotonous teaching methods used by lecturers so far can also be one of the factors that make it difficult for students to understand English texts. Therefore, we need a learning model such as flipped learning to overcome these problems. With flipped learning, students are expected to receive more frequent exposure to English both orally and in writing. The spoken English exposure can be seen and heard repeatedly through the recorded video. The oral English presentation can then be rewritten into written text, so that students' listening and writing competencies are indirectly honed here. All activities of watching and listening to videos as well as writing English subtitles were carried out at home. This can make students more free to experiment at home because they don't need to be embarrassed if they are wrong. As for the things that are not understood by the students from the video, they can then be conveyed to the lecturer during the learning hours. Thus, the flipped learning model is expected to improve students' understanding of English texts. 


\section{LITERATURE REVIEW}

\subsection{Learning Model}

The learning model is the entire learning system that is applied by lecturers or educators during the learning process, which consists of techniques, methods, strategies or approaches, even the learning media used (Komalasari, 2011: 57). The learning model used by the lecturer is structured based on thoughts about what and how students will receive instruction. All activities that are implemented must be well planned so that the implementation of the learning model is successful and the learning objectives can be achieved properly (Trianto, 2009: 23). This is also in line with the thinking (Joyce \& Weil (in Rusman, 2012: 133)) which states that a learning model is a plan or pattern used to form or design a learning plan. Therefore, the proper mastery and use of several theories regarding the learning model by lecturers is needed in order to produce a fun learning process and can improve student learning outcomes.

\subsection{Flipped Learning}

The term e-learning first appeared as a form of breakthrough in the world of education in the era of globalization. This technology-based learning system has become a pioneer from the emergence of other learning systems that are similarly based. Technology, in this case the use of computers in learning, is the main key to the existence of e-learning. Furthermore, technology develops progressively, one of which is marked by the emergence of the internet. The existence of the internet has influenced all aspects of the life of the world community. World information can be accessed anytime and anywhere. This has led to an online learning system or online learning. Now, it is not difficult to get knowledge about anything, because with an unlimited number, anything can be accessed whenever and wherever we are, online learning systems are now widely practiced in the world of education. However, the online system in the learning process also does not necessarily make students experience maximum achievement, because emotionally students still need a lecturer as an instructor, facilitator and motivator who guides and directs students directly, especially in teaching foreign languages. Therefore, technology-based teaching while maintaining the presence of lecturers in teaching will create a maximum learning system. This learning system is called the flipped learning system.

Several studies on the effectiveness of learning have been developed learning models. One of them is the Flipped Classroom, which is a model reverse learning or reversing the class applied by the lecturer to students. Model learning flipped classroom dismantles traditional classrooms in general. It has become a lecturer routine, namely providing material in class and then giving assignments to work on in class and outside of class. Recent technological developments have raises blended learning classes. Inverted (or reversed) class is of a particular type from blended learning designs that use technology for outside learning class and conduct classroom learning activities by practicing understanding of the material. (Strayer 2012).

In today's digital era, teaching and learning activities are carried out by utilizing existing technology. It is undeniable that technology has now become an important element in improving science. The existence of technology today has also changed the existing learning system in the world of education.

There has been a paradigm shift in education, from a lecturer-centered learning strategy to a student-centered learning strategy, one of which is technology-based or online learning. With technology, students will be much more active in seeking knowledge. Even so, the presence of lecturers is still very much needed in building the knowledge that students acquire. With flipped learning, technology can be used as a learning support medium while maintaining the presence of lecturers in the classroom. This flipped learning model utilizes media in the form of videos. This video application (which can record sound or images) can be used by students to record the ongoing learning process. Students can use cellphones to record the learning process. The concept of flipped learning is that activities that are usually carried out during the learning process are now carried out at home, and vice versa, activities that are usually carried out at home (known as the term PR (Homework)), are now carried out during the learning process (Yulietri, Fradila, Mulyoto \& Leo Agung. 2015).

The video that is recorded will be watched by students at home, then students will learn the subject matter from the video. Students will make summaries, note important points and make questions from material they do not understand, which can be asked to the lecturer during the learning process. Students can discuss with friends online about the videos they watch.

So it can be concluded that the concept of flipped learning, which is usually in the traditional learning model, the learning system is carried out properly, namely face-to-face or online, now done at home, and homework which is usually done at home, is now done in the process ongoing learning.

\section{METHOD}

This research is planned to be conducted for 1 year. The data was collected by using qualitative and quantitative methods. The data collected through qualitative methods is by conducting interviews and observations which will then be described in a narrative manner in this study, while the data collected through quantitative methods is obtained through statistical database analysis.

Qualitative data in the form of interviews were obtained through students and lecturers, while quantitative data were obtained through pre-test and post- 
test which were given to students in two different class groups. One class group will be given teaching using the flipped learning model and this group will then be referred to as the control class. Meanwhile, one other group will be given teaching using traditional learning models and are called intervention classes.

Both the control and intervention groups will be given a pre-test to determine the extent of students' reading ability to English text. Furthermore, the data obtained in the form of pre-test scores will later become a reference for researchers in making comparisons with the post-test scores given after each learning model is given. Furthermore, the data obtained from the pretest and posttest will be analyzed through univariate analysis and independent $t$ test using SPSS.

\section{RESULT AND DISCUSSION}

The design of this study begins with conducting a pretest on two groups / groups of students, to determine the difference in initial conditions between the two groups / groups of students. The group / group of students learning English using the flipped learning model is then called the experimental group, while the group / group of students learning English using traditional methods (lectures and discussions) is called the control group. In the traditional method, researchers in each meeting teach by lecturing, discussing, and giving assignments to students, and students complete these assignments in their respective homes.

In contrast to the traditional method, in the flipped learning method, classrooms are reversed to be more spent at home. The lecturer asks students to watch the learning video that was deliberately recorded during the learning process again. The next day, students in groups practice the lessons through assignments / activities in accordance with the direction / guidance of the lecturer. After several practical activities, students took a quiz to test their understanding. The quiz that is carried out will then be referred to as a post test. The post-test score in the experimental group increased significantly. This can be shown by the following calculation results:

\subsection{Validity Results}

Table 1. Item-Total Statistics

\begin{tabular}{|c|c|c|c|c|}
\hline & $\begin{array}{c}\text { Scale } \\
\text { Mean if } \\
\text { Item } \\
\text { Deleted }\end{array}$ & $\begin{array}{c}\text { Scale } \\
\text { Variance if } \\
\text { Item Deleted }\end{array}$ & \begin{tabular}{|c|} 
Corrected \\
Item-Total \\
Correlation \\
\end{tabular} & $\begin{array}{l}\text { Cronbach's } \\
\text { Alpha if } \\
\text { Item } \\
\text { Deleted }\end{array}$ \\
\hline P2 & 11.3000 & 13.390 & .135 & .690 \\
\hline P4 & 11.1667 & 13.040 & .323 & .674 \\
\hline P5 & 11.2667 & 13.168 & .214 & .682 \\
\hline P6 & 11.4333 & 12.737 & .300 & .674 \\
\hline P8 & 11.3667 & 14.585 & -.202 & .721 \\
\hline P10 & 11.5667 & 12.461 & .381 & .666 \\
\hline P12 & 11.5000 & 12.879 & .255 & .679 \\
\hline P13 & 11.6667 & 12.023 & .546 & .649 \\
\hline P14 & 11.3667 & 12.516 & .379 & .666 \\
\hline P16 & 11.5000 & 12.741 & .294 & .675 \\
\hline P17 & 11.3667 & 12.723 & .316 & .673 \\
\hline P18 & 11.5000 & 15.155 & -.340 & .735 \\
\hline P19 & 11.4333 & 12.875 & .260 & .678 \\
\hline P20 & 11.2000 & 12.648 & .434 & .664 \\
\hline $\mathrm{P} 22$ & 11.6667 & 12.713 & .329 & .671 \\
\hline $\mathrm{P} 23$ & 11.1667 & 12.764 & .429 & .666 \\
\hline P25 & 11.5333 & 13.085 & .198 & .684 \\
\hline P26 & 11.4667 & 12.120 & .479 & .655 \\
\hline P27 & 11.6667 & 13.057 & .226 & .681 \\
\hline P28 & 11.3667 & 13.137 & .195 & .685 \\
\hline P29 & 11.5000 & 12.328 & .415 & .662 \\
\hline
\end{tabular}

Based on the data validity of the questions in the table above, there are 29 valid questions. This data is found in the question items:

P2,P4,P5,P6,P8,P10,P12,P13,P14,P16,P17,P18,P19,P20 ,P22,P23,P25,P26,P27,P28, and P29

\subsection{Reliability Test}

Table 2. Reliability Statistics

\begin{tabular}{|r|r|}
\hline $\begin{array}{c}\text { Cronbach's } \\
\text { Alpha }\end{array}$ & N of Items \\
\hline .689 & 21 \\
\hline
\end{tabular}

Based on the results of the reliability test with the Cronbach alpha formula, it can be seen that the significance value is 0.689 which is greater than the significance value of 0.05 . Then the data is RELIABLE. 


\subsection{Normality Test}

Table 3. One-Sample Kolmogorov-Smirnov Test

\begin{tabular}{|c|c|c|c|}
\hline & & PRETEST & POSTTEST \\
\hline $\mathrm{N}$ & & 30 & 30 \\
\hline \multirow[t]{2}{*}{ Normal Parameters ${ }^{\mathrm{a}, \mathrm{b}}$} & Mean & 66.50 & 78.17 \\
\hline & Std. Deviation & 14.393 & 11.332 \\
\hline \multirow[t]{3}{*}{ Most Extreme Differences } & Absolute & .159 & .185 \\
\hline & Positive & .141 & .111 \\
\hline & Negative & -.159 & -.185 \\
\hline Kolmogorov-Smirnov Z & & .872 & 1.014 \\
\hline Asymp. Sig. (2-tailed) & & .433 & .255 \\
\hline
\end{tabular}

a. Test distribution is Normal.

b. Calculated from data.

Based on the table, it can be seen that the significance value of Sig. (2-tailed) is 0.255 which is greater than the significance value of 0.05 , so the data has a NORMAL distribution.

\subsection{Homogeneity Test}

Table 4. Test of Homogeneity of Variance

\begin{tabular}{|c|c|c|c|c|c|}
\hline & & Levene Statistic & df1 & df2 & Sig. \\
\hline \multirow{4}{*}{$\begin{array}{l}\text { STUDENT LEARNING } \\
\text { OUTCOMES }\end{array}$} & Based on Mean & .330 & 1 & 58 & .568 \\
\hline & Based on Median & .260 & 1 & 58 & .612 \\
\hline & $\begin{array}{l}\text { Based on Median and with } \\
\text { adjusted df }\end{array}$ & .260 & 1 & 53.790 & .612 \\
\hline & Based on trimmed mean & .299 & 1 & 58 & .587 \\
\hline
\end{tabular}

Seen in the test table of homogeneity of variance, there is a significance value Based on Mean of 0.568 , which is greater than the significance value of 0.05 , so the data is declared HOMOGEN.

\section{5. $T$ test}

Table 5. Paired Samples Statistics

\begin{tabular}{|rl|r|r|r|r|}
\hline & & Mean & N & Std. Deviation & Std. Error Mean \\
\hline Pair 1 & pre test & 66.50 & 30 & 14.393 & 2.628 \\
& post test & 78.17 & 30 & 11.332 & 2.069 \\
\hline
\end{tabular}

Seen in the table, there is an average pretest score of 66.50 and posttest of 78.17 from 30 respondents with a standard deviation of 14,393 pretest and 11,323 posttest. There is a significant difference in values between the pretest and posttest scores of the experimental class.

Table 6. Paired Samples Test

\begin{tabular}{|c|c|c|c|c|c|c|c|c|}
\hline & \multicolumn{5}{|c|}{ Paired Differences } & \multirow[b]{3}{*}{$\mathrm{t}$} & \multirow[b]{3}{*}{$\mathrm{df}$} & \multirow{3}{*}{$\begin{array}{l}\text { Sig. }(2- \\
\text { tailed) }\end{array}$} \\
\hline & \multirow[b]{2}{*}{ Mean } & \multirow{2}{*}{$\begin{array}{c}\text { Std. } \\
\text { Deviation }\end{array}$} & \multirow{2}{*}{$\begin{array}{c}\text { Std. Error } \\
\text { Mean }\end{array}$} & \multicolumn{2}{|c|}{$\begin{array}{l}\text {,05\% Confidence Interval of the } \\
\text { Difference }\end{array}$} & & & \\
\hline & & & & Lower & Upper & & & \\
\hline $\begin{array}{ll}\text { Pair 1 } & \text { pre test - } \\
\text { post test }\end{array}$ & -11.667 & 14.817 & 2.705 & -11.668 & -11.665 & -4.313 & 29 & .000 \\
\hline
\end{tabular}


Based on the significance value in the paired sample test table which gets a Sig (2-tailed) value of 0.000 , which is less than 0.05 , there is an influence on this research.

In the experimental group / group, students received exposure to new material, namely English narrative text through a learning video. Students then watched the video in their respective homes to assimilate knowledge about the material given. Students learn at their own pace and at their own pace. Students replay certain sections, pause, and even rewatch the entire video several times. The ability of students to understand the given English text varies. Some can immediately understand it in just 1 (one) watch, but some have to watch dozens of times to understand. However, the goal is reading comprehension on the English text.

The researcher begins the lesson by making a short video that begins with the material "Narrative Text" which includes: characteristics, types, structure and examples of narrative text in English. Furthermore, in the video, the researcher also reads an English narrative text with good and correct pronunciation. The researcher describes the story in narrative text according to the context so that students can easily understand the content of the story. If necessary, occasionally the researcher makes a movement or body language to make it easier for students to understand the meaning of a word / sentence.

Furthermore, the researcher shows how the concept of narrative text briefly through simple animation. Students are more interested in watching animated videos and are ready to understand more about the topic at the next meeting. Videos can also be watched by parents, which in turn increases parents' understanding of children's homework topics and can support children's learning at home so that children are more confident in doing assignments.

Flipped learning is the right learning model solution to be applied in a pandemic like today. Students have access to videos anytime and anywhere to review all material obtained during the lecture. Students also do not need to worry about missing course material because students can freely rewind, pause, and replay the learning video. This makes it easier for students to understand or understand the course material better. Especially in learning English, the constant repetition of the language can strengthen students in English pronunciation and understanding. If students have difficulty understanding the subject matter, students can prepare questions to be asked at the next meeting. Here, parents also don't have to be teachers at home because students are active learners. Researchers emphasize that students are obliged to make questions from each learning video that has been observed. When questions arise in students' minds, students are unconsciously motivated to think about solving these problems, so that the goal is that new understandings emerge in knowledge (Nasution; 2000: 161).

\section{CONCLUSION}

In flipped learning, students can get time which is the most valuable teaching resource. Flipped learning does not shorten the meeting, but gives students more time to use in active learning by reallocating teaching and learning time at home. Flipped learning improves communication between lecturers and parents, because parents can tell the lecturer specifically where in the learning process children experience difficulties or which parts of the concept of learning material are being tried by the child to understand.

In the control group, the course material given was the same as that given to the experimental group, namely regarding the narrative text. The researcher explains the narrative text by giving examples of the text and reading the text in turn. Then discuss it together and answer existing questions related to the narrative text. Furthermore, students are given slightly different questions but still with the same narrative text, which will be referred to as the post test. The post-test scores in the control group did not show any improvement. After that, the researcher will provide other narrative texts to students and give assignments to answer questions related to the text in each house. However, the results of the questionnaire stated that often students did not answer the questions correctly.

\section{REFERENCES}

[1] Arnold-Garza, S. (2014). The Flipped Classroom Teaching Model and Its Use for Information Literacy Instruction. Communications in Information Literacy, 8 (1), 7-22.

[2] Bergmann, J., and Sams, A. (2012). Flip your classroom: Reach every student in every class every day. Washington, DC: ISTE; and Alexandria, VA: ASCD.

[3] Hung, H. (2015). Flipping the classroom for English language learners to foster active learning, Computer Assisted Language Learning, 28 (1), 8196.

[4] Komalasari, kokom. 2011. Pembelajaran Kontekstual Konsep dan Aplikasi. Bandung: PT Refika Aditama.

[5] Ozdamli, F. \& Asiksoy, G. (2016). Flipped classroom approach. World Journal on Educational Technology: Current Issues. 8(2), 98-105.

[6] Rusman, Kurniawan, dan Riyana. 2012. Pembelajaran Berbasis Teknologi Informasi dan Komunikasi, Mengembangkan Profesionalitas Guru. Jakarta: Raja Grafindo Persada.

[7] Trianto (2009). Mendesain Model Pembelajaran Inovatif Progresif.Surabaya:Kencana

[8] Yulietri, Fradila, Mulyoto \& Leo Agung. 2015. "Model Flipped Classroom dan Discovery Learning 
pengaruhnya terhadap Prestasi Belajar Matematika ditinjau dari Kemandirian Belajar”. Teknodika, 13 (2): 5-17.

[9] Zainuddin, Z., Habiburrahim, H., Muluk, S., \& Keumala, C. M. (2019). How do students become self-directed learners in the EFL flipped-class pedagogy? A study in higher education. Indonesian Journal of Applied Linguistics, 8(3), 678-690. 